\title{
Seismic reflection profiling across the source fault of the 2003 Northern Miyagi earthquake (Mj 6.4), NE Japan: basin inversion of Miocene back-arc rift
}

\author{
Naoko Kato $^{1}$, Hiroshi Sato ${ }^{1}$, Toshifumi Imaizumi ${ }^{2}$, Yasutaka Ikeda ${ }^{3}$, Shinsuke Okada ${ }^{3}$, Kyoko Kagohara ${ }^{4}$, \\ Taku Kawanaka $^{5}$, and Keiji Kasahara ${ }^{6}$ \\ ${ }^{1}$ Earthquake Research Institute, University of Tokyo, 1-1-1 Yayoi, Bunkyo-ku, Tokyo 113-0032, Japan \\ ${ }^{2}$ Department of GeoEnvironmental Science, Tohoku University, Sendai 980-8578, Japan \\ ${ }^{3}$ Department of Earth and Planetary Science, University of Tokyo, Tokyo 113-0033, Japan \\ ${ }^{4}$ Graduate School of Medical and Engineering Science, Department of Education, Yamanashi University, Yamanashi 400-8510, Japan \\ ${ }^{5}$ JGI Inc., 1-5-21 Otsuka, Tokyo 112-0012, Japan \\ ${ }^{6}$ National Research Institute for Earth Science and Disaster Prevention, Tsukuba 305-0006, Japan
}

(Received May 27, 2004; Revised August 15, 2004; Accepted September 1, 2004)

\begin{abstract}
The Northern Miyagi earthquake (Mj 6.4) on 26 July, 2003, was a shallow crustal earthquake produced by high-angle reverse faulting. To construct a realistic geologic model for this fault system from depth to the surface, seismic reflection profiling was carried out across the northern part of the source fault of this earthquake. The common mid-point seismic reflection data were acquired using a vibrator truck along a $12 \mathrm{~km}$-long seismic line. The obtained seismic profile portrays a Miocene half-graben bounded by a west-dipping fault. Consistent with gravity anomaly data, the maximum thickness of the basin fill probably reaches $3 \mathrm{~km}$. From the regional geology, this basin-bounding normal fault forms the eastern edge of the northern Honshu rift system and was produced by rapid extension during 17-15 Ma. The deeper extension of the fault revealed by seismic profiling coincides with the planar distribution of aftershocks. The hypocentral distribution of the aftershocks shows a concentration on a plane dipping 55 degrees to the west with listric geometry. Thus, the basin inversion has been performed using the same fault; the 2003 Northern Miyagi earthquake was generated by fault reactivation of a Miocene normal fault.
\end{abstract}

Key words: Seismic reflection profiling, 2003 Northern Miyagi earthquake, basin inversion, Miocene back-arc rift, fault reactivation, NE Japan.

\section{Introduction}

The Northern Miyagi earthquake (Mj 6.4, Mj: Japan Meteorological Agency magnitude) occurred at 7:13 (JST) on 26 July, 2003, just after an earthquake of Mj 5.6 (0:13 JST) and was followed by an earthquake of Mj 5.5 (16:56 JST). The focal depth of the main shock was about $12 \mathrm{~km}$ and its focal mechanism was reverse faulting (Umino et al., 2003). No surface ruptures associated with the earthquakes were found by our field observation and no active faults were identified from detailed seismic observations along the shallower extension of the estimated source fault from detailed seismic observations (Umino et al., 2003). The geometry of the source fault is clearly indicated by the aftershock distribution determined by dense temporary seismic observations (Umino et al., 2003). However, the geometry of the shallower extension of the source fault and the surrounding geologic structure are poorly understood. To construct a realistic geologic model for the source fault and its surface extension, it is important to assess the seismic hazard risk produced by crustal faults. Within such a context, seismic reflection profiling was carried out across the source fault of the 2003 Northern Miyagi earthquake. This paper de-

Copy right(c) The Society of Geomagnetism and Earth, Planetary and Space Sciences (SGEPSS); The Seismological Society of Japan; The Volcanological Society of Japan; The Geodetic Society of Japan; The Japanese Society for Planetary Sciences; TERRAPUB scribes the result of the seismic reflection profiling and discusses the fault evolution associated with basin formation and subsequent basin inversion processes.

\section{Geologic Setting}

The damaged area is located in the eastern rim of the Miocene northern Honshu rift system (Sato et al., 2004a) and is the boundary between the Neogene rocks and the Paleozoic and Mesozoic rocks of the Kitakami Mountains (Fig. 1). The western margin of the Kitakami Mountains is marked by a steep gradient zone of a Bouguer anomaly trending NS, which was formed as a normal fault in the early Miocene. The main Neogene geologic structure of northern Honshu trends NS in the northern part and NESW in the southern part. The fore-arc side of central northern Honshu corresponds to the junction of these two parts and normal faults, trending in several directions such as NS, NE-SW and WNW-ESE, were formed by early Miocene extension (e.g. Sato et al., 2002). Recent tectonic movements have been strongly controlled by fault reactivation of these Miocene faults under WNW-ESE compression since the late Pliocene (e.g. Nakamura, 1992; Sato, 1994; Sato et al., 2002).

The geologic map around the area damaged by the 2003 Northern Miyagi earthquake is shown in Fig. 2. Marine Miocene sedimentary rocks are widely distributed in 


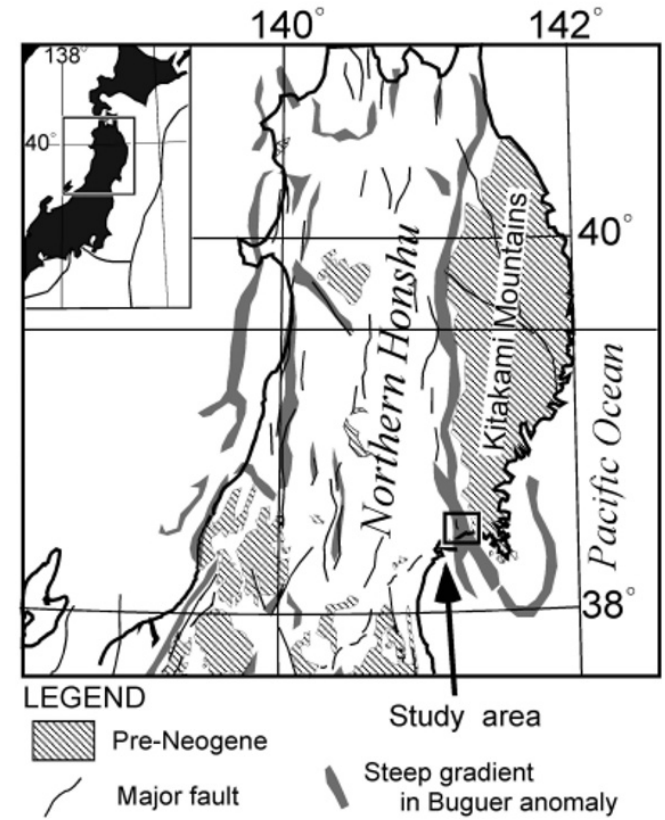

Fig. 1. Location map showing the study area and the major geologic structure of northern Honshu.

the Asahiyama and Sue Hills (Ishii et al., 1982; Fig. 2). The Miocene basin fill is divided into two units; the Matsushima-wan Group (mainly syn-rift sediments) and the Shida Group (post-rift sediments). The Matsushima-wan Group consists of volcanic and volcaniclastic rocks, fluviolucastrine sediments and marine-interbeded sandstone and siltstone in ascending order (Ishii et al., 1982). The Shida Group, a shallow marine sandstone, is unconformably overlying the Matsushima-wan Group. In this paper, according to the age of the Oido Formation (15.0 and 12.9 Ma; Ishii and Yanagisawa, 1984), we have included the Oido Formation in the Shida Group, except for the Kakeyama conglomerate member distributed at the Sue Hills. From a lithostratigraphic point of view, as the Kakeyama conglomerate member is a syn-rift sediment, we renamed it the Kakeyama Formation and included it as a lithostratigraphic unit within the Mastushima-wan Group. Since the late middle Miocene, this area has been tectonically stable and sedimentaion has been controlled mainly by eustatic sea-level changes. The Pliocene marine sediments are unconformably overlying the lower strata.

The Asahiyama Hills form a gentle anticline trending NS and its eastern limb, including the Pliocene strata, shows a flexure dipping to the east up to 50 degrees. Based on tectonic geomorphological research, this Asahiyama flexure shows late Quaternary tectonic movements (Ishii et al., 1982).

\section{Kanan 2003 Seismic Survey}

\subsection{Data acquisition and processing}

The Northern Miyagi earthquakes occurred across NESW and N-S trending faults (Umino et al., 2003). Our seismic reflection profile (Kanan, 2003) was acquired across the $\mathrm{N}-\mathrm{S}$ trending source fault estimated by aftershock seismicity. The length of the seismic line is $12 \mathrm{~km}$. Data acquisi- tion parameters are shown in Table 1. Vibroseis and minivibrator trucks were used for seismic sources with sweep frequencies of 8-90 and 8-75 Hz, respectively. The minivibrator truck was operated in narrow roads not accessible for the vibroseis truck (CMP340-460, Fig. 2). Usually, we set the shot and receiver interval to $25 \mathrm{~m}$ and, in order to improve spatial resolution, the interval was $12.5 \mathrm{~m}$ at some shot points at the eastern edge of the Sue Hills. The seismic signals were recorded by a digital telemetry system (JGI, GDAPS-4A).

The obtained seismic reflection data were processed by conventional Common mid-point (CMP) methods, including post-stack migration and depth conversion. Static correction for weathering layers was applied, based on refraction analysis using the time-term method. Processing parameters used in the Kanan 2003 seismic survey are shown in Table 2. The stacked time section is shown in Fig. 3(a). The most continuous reflections are less than $1.2 \mathrm{~s}$ TWT (two-way travel time). The depth converted seismic section is shown in Fig. 3(b).

\subsection{Interpretation of seismic data}

A geologic interpretation is shown in Fig. 3(b). Based on the result of velocity analysis and reflection patterns, we interpreted the upper surface of the pre-Tertiary basement to be horizon D in Fig. 3(b). It is marked by relatively large amplitudes and reflected low frequencies. The lower part of the section below horizon D is characterized by poor seismic reflectors. At the eastern end of the seismic section, the top of the basement (horizon D) is recognized to be 100-

Table 1. Date acquisition parameters of the Kanan 2003 seismic survey.

\begin{tabular}{|c|c|}
\hline $\begin{array}{l}\text { Length of seismic line } \\
\text { Source parameters }\end{array}$ & $12 \mathrm{~km}$ \\
\hline $\begin{array}{l}\text { Source paramelers } \\
\text { Source }\end{array}$ & $\begin{array}{l}\text { Vibrator (IVI, Y2400) or } \\
\text { Mini-vibrator (IVI T-15000) }\end{array}$ \\
\hline Sweep frequency & $8-75 \mathrm{~Hz}$ or $8-90 \mathrm{~Hz}$ \\
\hline Sweep length & $20 \mathrm{~s}$ \\
\hline No. of sweeps & 5 \\
\hline No. of shot points & 455 \\
\hline Shot interval & $25 \mathrm{~m} \quad(12.5 \mathrm{~m}$ for CMP680-690) \\
\hline \multicolumn{2}{|l|}{ Receiver parameters } \\
\hline Natural frequency & $10 \mathrm{~Hz}$ \\
\hline Receiver interval & $25 \mathrm{~m}$ \\
\hline No. of channels & 240 or 286 \\
\hline \multicolumn{2}{|l|}{ Recording parameters } \\
\hline Instruments & JGI, GDAPS-4A \\
\hline Sampling interval & $4 \mathrm{~ms}$ \\
\hline Recording length & $5 \mathrm{sec}$ \\
\hline Standard CMP fold & 130 \\
\hline
\end{tabular}

Table 2. Processing parameters used for the Kanan 2003 seismic data.

CDP Sorting CMP interval: $12.5 \mathrm{~m}$
Static Correction by Refraction Analysis: two layers model $(800 \mathrm{~m} / \mathrm{s}$,
and higher velocity layer), Time-term method
Gain RecoveryGate length: $5000 \mathrm{~ms}$
Predictive Deconvolution Gate length: $5000 \mathrm{~ms}$, Operator length:
$\quad 200 \mathrm{~ms}$, White noise : $5 \%$, Prediction length : $16 \mathrm{~ms}$
Velocity Analysis Velocity scan at every $50 \mathrm{CMP}$
F-X Prediction Filter Gate length: 30 traces, Operator length:
5 traces, Window length: $1000 \mathrm{~ms}$
Band-pass Filter
Frequency $8 / 10-50 / 55 \mathrm{~Hz}$
Post-stack Time Migration
velocity scaling ( $90 \%)$




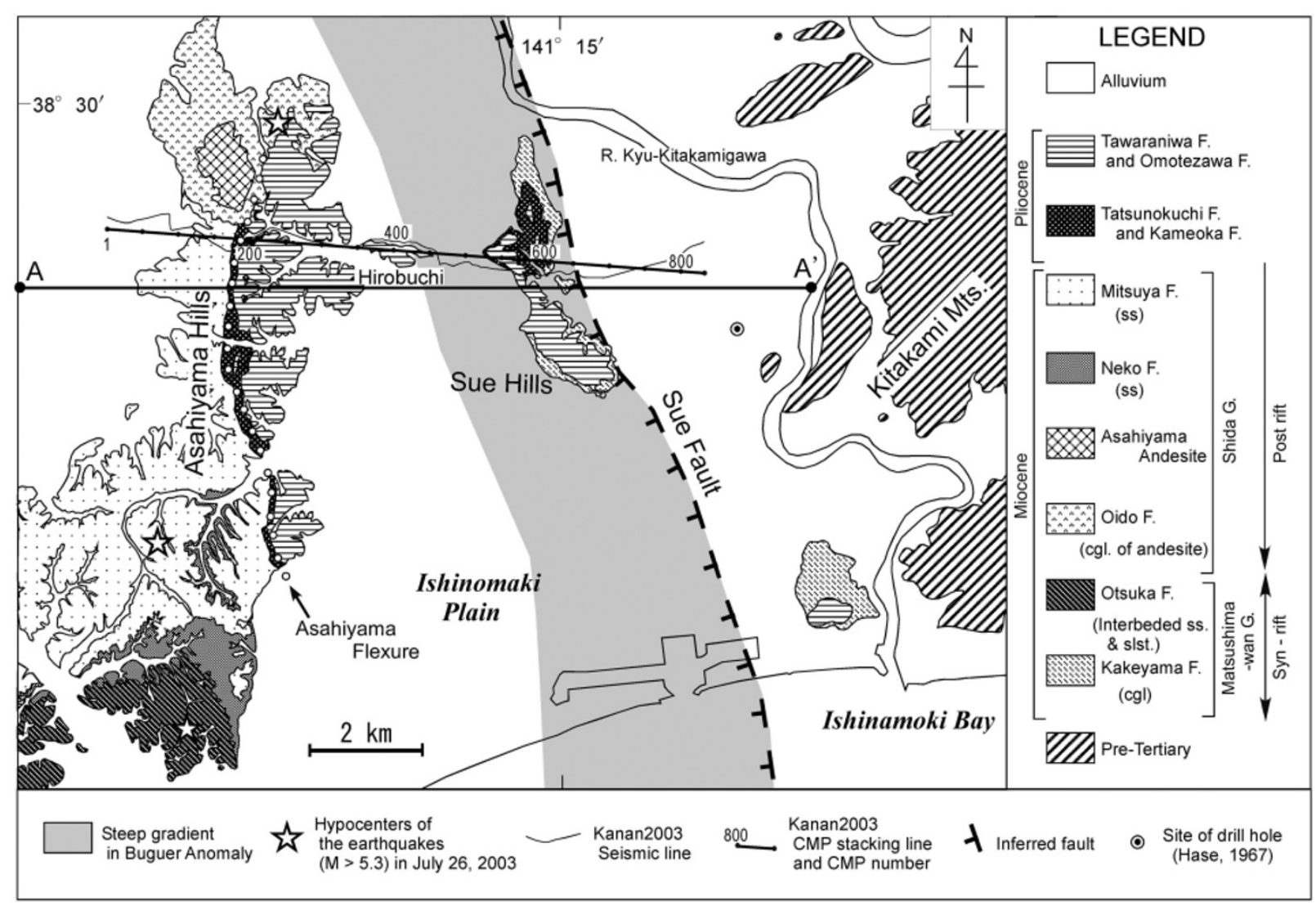

Fig. 2. Geologic map around the area damaged by the 2003 Northern Miyagi earthquake after Ishii et al. (1982), Takahashi et al. (1969) and Takizawa et al. (1984). A-A': see Fig. 5. Litho-facies include: cgl: conglomerate, ss: sandstone, slst: siltstone.

$200 \mathrm{~m}$ in depth, which increases to the west. According to a drill hole located at near the eastern end of the seismic line (Fig. 2), 60 m-thick Quaternary sediments unconformably cover the pre-Quaternary rocks near the eastern end of the seismic line (Hase, 1967). The low velocity strata above horizon D, beneath the Ishinomaki plain (CMP 650-818), probably consist of Pliocene to Quaternary sediments. The western extension of horizon $\mathrm{D}$ is not traceable between CMP 300-600 but is again identified between CMP 60-300 at $2-2.5 \mathrm{~km}$ depth. According to the CMP velocity analysis, the estimated velocity of rocks below horizon C (Fig. 3(b); CMP 300-600) is higher than that of the reflective upper layers, but is smaller than that of pre-Tertiary rocks. Thus, we estimated that horizon D appears east-dipping, as shown by the broken line in Fig. 3(b). Based on the lateral discontinuity of the pre-Tertiary upper surface (horizon D) and other horizons, the west-dipping Sue fault can be identified at the eastern end of the Sue Hills. Judging from the litho-faces of the Kakeyama Formation cropping out at the Sue Hills, the reflections between horizons $\mathrm{D}$ and $\mathrm{C}$ probably consist of a thick conglomerate deposited as talus and footwall fans.

The shallower part of the profile above horizon $\mathrm{C}$ is characterized by a large number of reflectors. Horizon $\mathrm{B}$ is identified as an unconformity. Based on the patterns of reflections and drill hole, the strata below horizon B are interpreted as the early to middle Miocene Matsushima-wan Group (syn-rift sediments) and the strata between horizons A and B correspond to the middle to late Miocene Shida Group (post-rift sediments) (Sato et al., 2004b). From the surface geology, the base of the Pliocene sediments is shown as horizon A on the seismic section (Fig. 3(b)).

\section{Density Structural Model by Gravity Data}

The energy of the seismic source in the Kanan 2003 seismic survey is not strong enough to obtain a clear image of the base of Neogene sediments between CMP 300-600. To obtain the geometry of the Neogene sedimentary package, a density structural model along the seismic line was analyzed using gravity data provided by the Geological Survey of Japan (2000). Gravity data measured at 83 points located within $2 \mathrm{~km}$ width of the seismic survey line were used in this study. The effect of subduction of the Pacific plate was removed from the gravity data. We created a twodimensional, four-layer model. The layer geometry is obtained from the interpreted geologic section. The density layers are classified into four units: (Layer-1) Neogene to Quaternary sediments except for the Kakeyama Formation (conglomerate); (Layer-2) lower to middle Miocene conglomerate (Kakeyama Formation); (Layer-3) Pliocene to Quaternary sediments in the east of the Sue Hills (CMP 640-818); and (Layer-4) pre-Tertiary rocks. The configuration of the basement under the eastern part of the Asahiyama Hills (CMP 150-300) and east of the Sue Hills (CMP 610-818) is fixed using the interpreted geologic section. That corresponds to the top of Layer-4. We determined the layer densities by an inversion method. Bouguer gravity anomalies were calculated using a reduction density of $2.67 \mathrm{~g} / \mathrm{cm}^{3}$. Calculations of gravity were carried out 
(a)

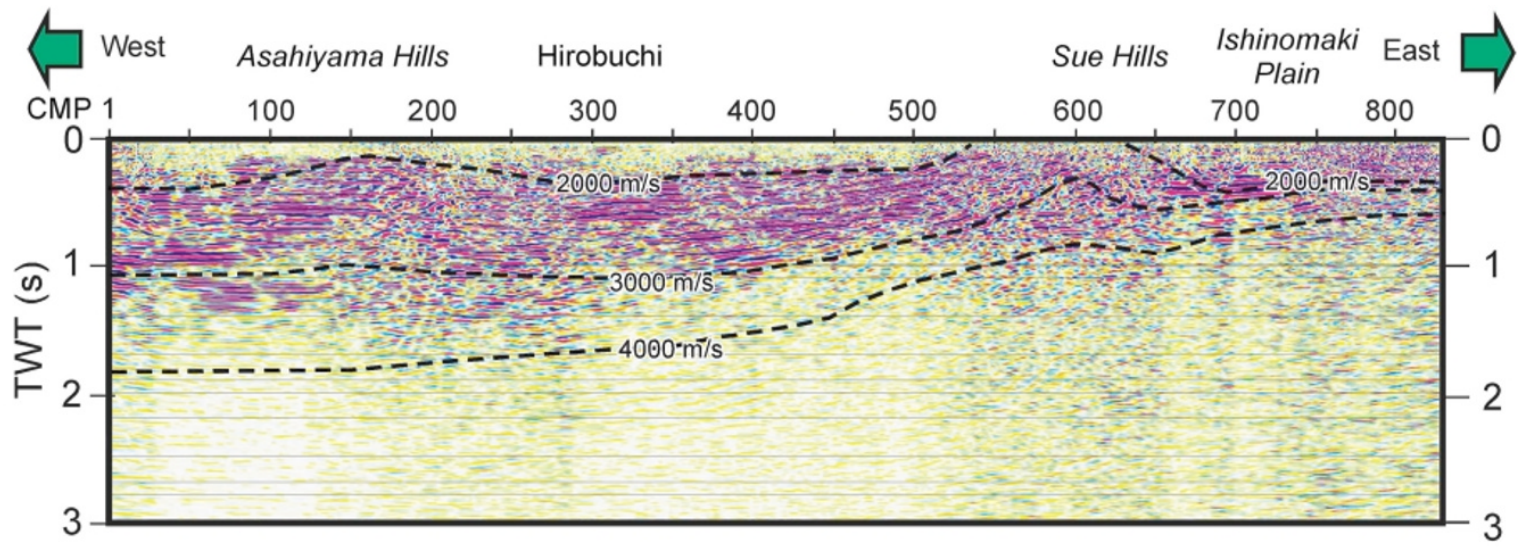

(b)

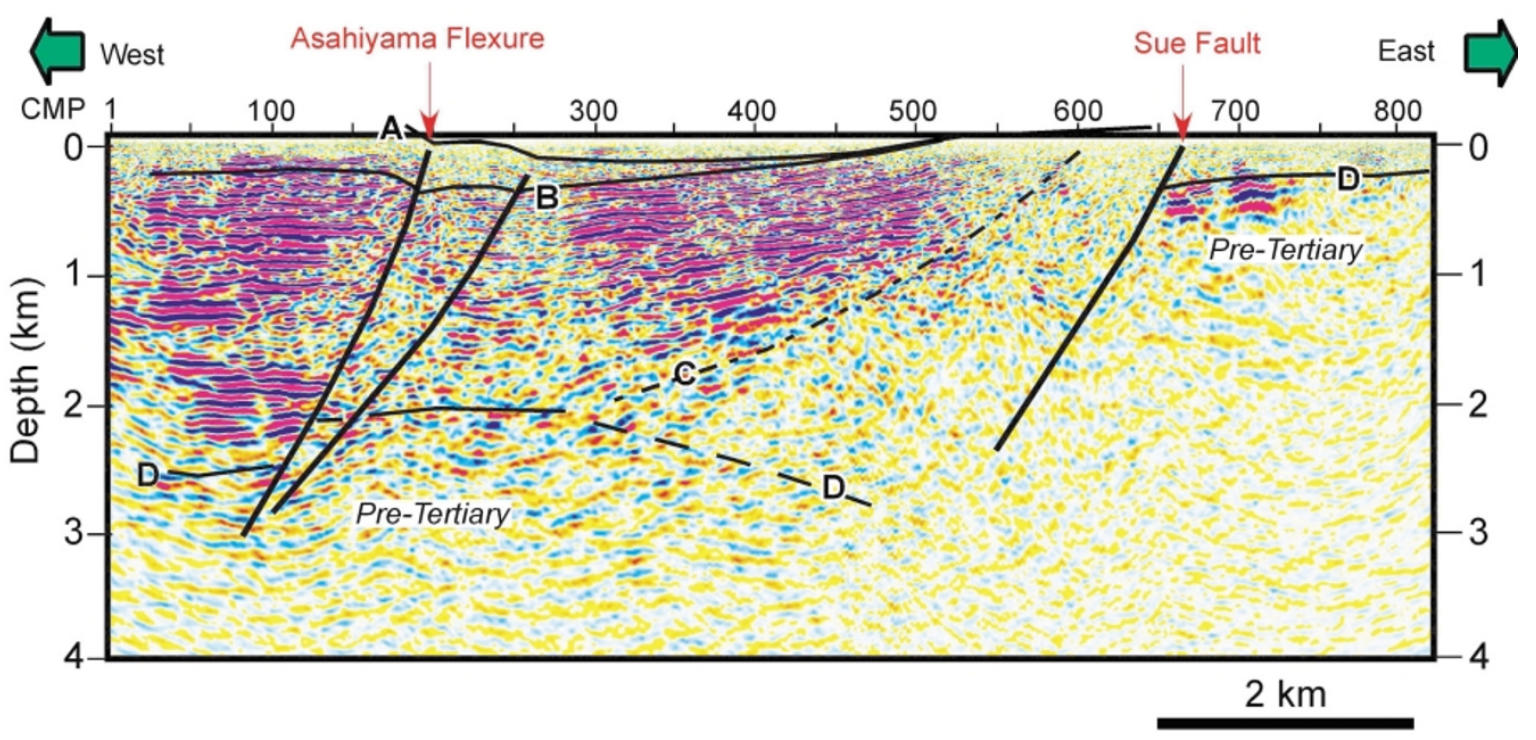

Fig. 3. (a) Stacked seismic section and stacking velocity. (b) Post-migrated, depth converted seismic section of the Kanan 2003 seismic survey and geologic interpretation.

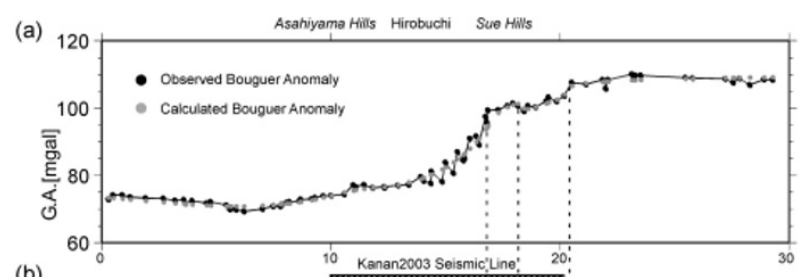

(b)

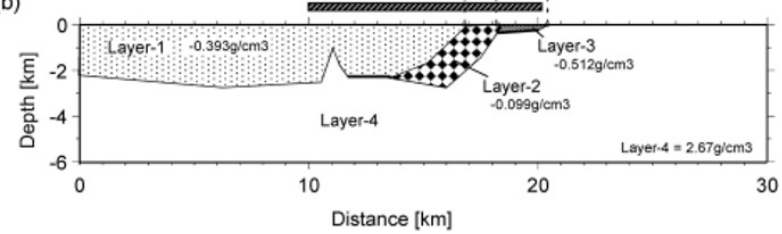

Fig. 4. Density model along the seismic line. (a) Calculated Bouguer anomaly and observed Bouguer anomaly after Geological Survey of Japan (2000). (b) Subsurface density structure determined from Bouguer anomaly.

using the Talwani et al. (1959) method.

Figure 4 shows the best-fit density structure determined by the inversion method, assuming the low density sediments (stratified units) and high density wedge-shaped sediments beneath the Sue Hills. The possible density structure model shows that the overall pattern of the Bouguer anomaly results from (A) low density sediments that thin eastward from the Asahiyama Hills to near the eastern margin of Sue Hills, (B) high density wedge-shaped sediments, probable conglomerate, under the Sue Hills to Hirobuchi. Under the above-mentioned assumption, the maximum depth to the base of Neogene is estimated to be $3 \mathrm{~km}$ at CMP 520. The cone-shaped Layer-4 at the western part of the seismic line beneath the Asahiyama Hills corresponds to the volcanic neck of the Asahiyama Andesite Member (Ishii et al., 1982).

\section{Discussion}

The extensional tectonics in the early to middle Miocene strongly affected the crustal structure of northern Honshu. Many Miocene half-grabens such as in the Tanakura area (Otsuki, 1975) and the Uetsu area (Yamaji, 1989), are marked by the deposition of a thick conglomerate showing more than $2 \mathrm{~km}$ of stratigraphic thickness. Our seismic section well represents the Miocene normal faulting associated with the deposition of thick coarse sediments on the hanging wall. Based on the thickness of the probable conglomerate estimated from the density model shown in Fig. 4, the total amount of vertical displacement of the Sue fault in the early to middle Miocene has the poten- 


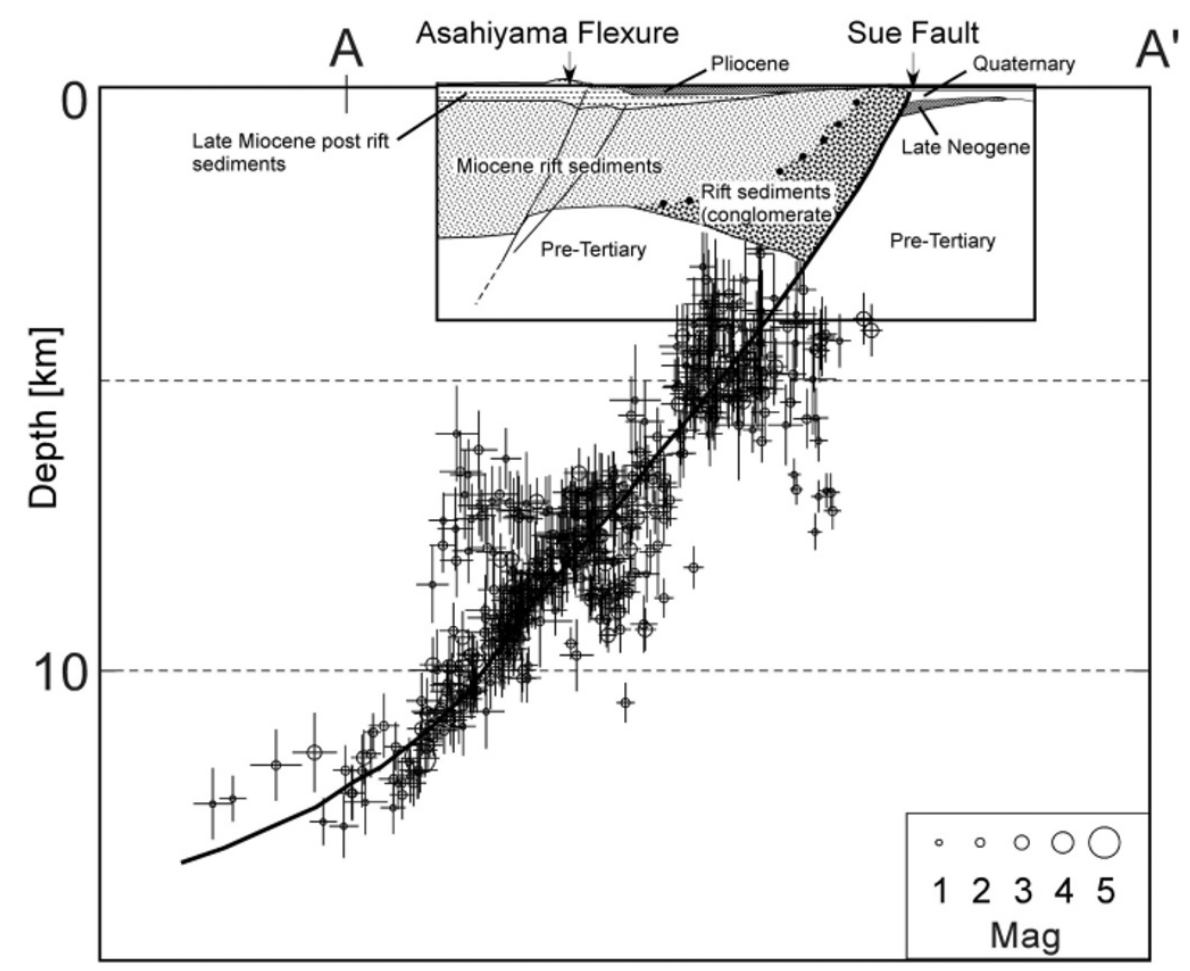

Fig. 5. Schematic diagram showing the relationship between aftershock distribution and shallow crustal structure. The aftershock distribution is after Umino et al. (2003). The location A-A' is shown in Fig. 2.

tial to reach $3 \mathrm{~km}$. The vertical displacement suggested by the Pliocene strata shows opposite movement of the fault (Fig. 3). As the westward-dipping Miocene strata are covered by the sub-horizontal Pliocene strata (horizon D) with clino-unconformity at the Sue Hills, the reverse faulting occurred in the latest Miocene. Judging from the lower Pliocene deformation along the Asahiyama flexure, the basin inversion occurred after ca. $3 \mathrm{Ma}$, suggesting younger faulting than that of the Sue fault. Due to a lack of drill holes in the footwall, the movement of the Sue fault in Pliocene to Quaternary is poorly understood.

Figure 5 shows the spatial relationship between the aftershock distribution (Umino et al., 2003) and the shallow crustal structure obtained by the seismic profiling and gravity analysis. The deeper extension of the Sue fault coincides with the planar distribution of aftershocks. The hypocentral distribution of the aftershocks shows a concentration on a plane dipping 55 degrees to the west with listric geometry. Using the deep fault geometry estimated from this aftershock concentration, the shape of the basin fill is restorable by forward modeling of balanced cross-sections. Thus, it is highly probable that the 2003 Northern Miyagi earthquake was generated by whole fault-reactivation within a seismogenic layer.

\section{Conclusions}

The seismic reflection profile and density modeling across the northern part of the source fault of the 2003 Northern Miyagi earthquake portray a Miocene halfgraben. Considering the distribution of the aftershocks, the earthquake was generated by reactivated reverse faulting of the Miocene basin-bounding normal-fault.
Acknowledgments. We are grateful to Yukio Yanagisawa, Norihito Umino, Tomomi Okada, Kenshiro Ohtsuki, Hideo Saito, Shigeyuki Suda, Takeshi Kozawa, and David Okaya for helpful discussions and comments. We also thank the JGI seismic crew and Sumiko Ogino for data acquisition. Thoughtful reviews by Anne-Marie Boullier, Yasuo Ogawa and the anonymous reviewer improved the manuscript. Seismic data processing used the Super-X package of JGI. The seismic experiments were supported by Grant-in-Aid for Scientific Research (15800009, 14209004, $15300300)$ provided by the Ministry of Education, Science, Culture and Sports.

\section{References}

Geological Survey of Japan (ed.), Gravity CD-ROM of Japan, Digital Geoscience Map P-2, Geological Survey of Japan, 2000.

Hase, K., Geology of the Alluvial Plains of Miyagi Prefecture, Tohoku Univ., Inst. Geol. Pal., Contr., 64, 1-45, 1967 (in Japanese with English abstract).

Ishii, T., Y. Yanagisawa, S. Yamaguchi, A. Sangawa, and K. Matsuno, Geology of the Matsushima district, with Geological Sheet Map at 1:50,000, Geological Survey of Japan, 121 pp., 1982 (in Japanese with English abstract).

Ishii, T. and Y. Yanagisawa, On the geologic age of the Oido Formation distribution in the Kyu-kitakami valley Region, northeast Honshu, Japan, Bull. Geol. Surv. Japan, 35, 623-635, 1984 (in Japanese with English abstract).

Nakamura, K., Inversion tectonics and its structural expression, J. Tectonic Res. Group Japan., 38, 3-45, 1992 (in Japanese with English abstract).

Otsuki, K., Geology of the Tanakura Shear Zone and Adjacent Area, Tohoku Univ., Inst. Geol. Pal. Contr., 76, 1-71, 1975 (in Japanese with English abstract).

Sato, H., The relationship between late Cenozoic tectonic events and stress field and basin development in northeast Japan, J. Geophys. Res., 99, 22261-22274, 1994.

Sato, H., T. Imaizumi, Y. Yoshida, H. Ito, and A. Hasegawa, Tectonic evolution and deep to shallow geometry of Nagamachi-Rifu Active Fault System, NE Japan, Earth Planets Space, 54, 1039-1043, 2002.

Sato, H., T. Yoshida, T. Iwasaki, T. Sato, Y. Ikeda, and N. Umino, Late Cenozoic tectonic development of the back arc region of central 
northern Honshu, Japan, revealed by recent deep seismic profiling, $J$. Japanese Association for Petroleum Technology, 96, 145-154, 2004a (in Japanese with English abstract).

Sato, H., N. Kato, T. Imaizumi, Y. Ikeda, S. Okada, K. Kagohara, S. Ogino, T. Kawanaka, and K. Kasahara, Seismic reflection and refraction profilings across the source fault of the 2003 Northern Miyagi earthquake, Report on the results of the Grant-in-Aid for Scientific Research, No. 15800009, Tohoku Univ., Sendai, 5-20, 2004b (in Japanese).

Takahashi, H. and K. Matsuno, Geology of the Wakuya district. with Geological Sheet Map at 1:50,000, Geological Survey of Japan, 26 pp, 1969 (in Japanese with English abstract).

Takizawa, F., N. Kambe, K. Kubo, M. Hata, A. Sangawa, and M. Katada, Geology of the Ishinomaki district, with Geological Sheet Map at 1:50,000, Geological Survey of Japan, 103 pp., 1984 (in Japanese with English abstract).

Talwani, M., J. L. Worzel, and M. Landisman, Rapid gravity computations for two-dimensional bodies with application to the Mendocino Submarine Fracture Zone, J. Geophys. Res., 64, 49-59, 1959.

Umino, N., T. Okada, J. Nakajima, S. Hori, T. Kono, T. Nakayama, N. Uchida, J. Shimizu, J. Suganuma, S. Gamage, A. Hasegawa, and Y Asano, Hypocenter and focal mechanism distributions of aftershocks of July 262003 M6.4 northern Miyagi, NE Japan, earthquake revealed by temporary seismic observation, Earth Planets Space, 55, 719-730, 2003.

Yamaji, A., Geology of Atsumi area and early Miocene rifting in the Uetsu district, northeast Japan, Mem. Geol. Soc. Jpn., 32, 305-320, 1989 (in Japanese with English abstract).

N. Kato (e-mail: naoko@eri.u-tokyo.ac.jp), H. Sato, T. Imaizumi, Y Ikeda, S. Okada, K. Kagohara, T. Kawanaka, and K. Kasahara 